\title{
An emperical study into the informal sector: The link between entrepreneurial activity and firm performance
}

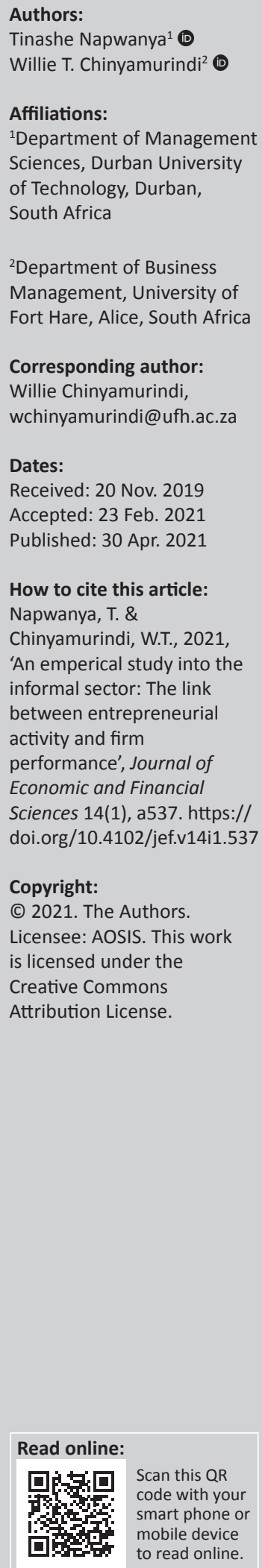

Orientation: Within an emerging market context, the informal sector's role was deemed critical towards achieving ideals of a developmental state. Given this perceived importance, there was a need to continually study informal sector entrepreneurial activity and its ramifications on firm performance.

Research Purpose: This study aimed to understand the link between informal sector entrepreneurial activities and firm performance using a sample of firms operating in Durban, South Africa.

Motivation of the study: Exploring those entrepreneurial activities that either enhanced or impeded the informal sector was deemed critical in the effectual and efficient operation of the sector. In driving the firm performance agenda ascertaining the role of factors such as (1) entrepreneurial culture, (2) entrepreneurial education and skills, (3) government and incubation support and finally, (4) access to finance can enhance the informal sector through the provision of evidence-based interventions.

Research approach/design/method: A quantitative survey research approach was used to collect data from 152 informal sector businesses operating in the city of Durban in South Africa. A convenience sampling technique was used to access the respondents. Data were analysed using the Statistical Package for Social Sciences (SPSS) programme version 23 using correlation and regression tests.

Main findings: The findings revealed the adoption of an entrepreneurship culture, including access to entrepreneurship education and skills to predict a firm's financial and non-financial performance significantly. Furthermore, it was found that government and incubation support predicted a firm's financial performance. However, it was also established that government and incubation support had no unique contribution to non-financial performance.

Practical/managerial implications: Suggestions were made based on the findings that entrepreneurial activities have a bearing on informal sector business performance. These findings became a helpful intervention towards enhancing the performance of informal businesses.

Contribution/value-add: This study contributed to understanding entrepreneurial activities that either enhanced or impeded informal businesses' performance.

Keywords: access to finance; entrepreneurship; entrepreneurship culture; entrepreneurial education; firm performance; government support; informal economy.

\section{Introduction}

The informal sector is one of the primary drivers of a country's economy (Fu, Mohnen \& Zanello 2018; Mintah \& Darkwah 2018). The informal sector has potential ramifications to lower the high unemployment rate, reduce poverty and close the income inequality characterising especially in developing countries (Alrawadieh \& Alrawadieh 2018; Başbay, Elgin \& Torul 2018). The majority of informal sector participants are usually necessity entrepreneurs (Serviere 2010), who are driven to start their businesses as a result of unemployment and the contraction of the formal sector (Alrawadieh \& Alrawadieh 2018; Bozhikin, Macke \& da Costa 2019; Rogerson 2018).

Despite the informal sector's noted importance and popularity, especially in South Africa (Global Entrepreneurship Monitor 2019; Mintah \& Darkwah 2018), calls exist within the theoretical and practitioner press. Firstly, there is notable concern in understanding better those factors that influence informal sector businesses. The challenge that often exists is how under-researched the informal sector is and the fragmented nature of this sector, especially in developing economies 
like South Africa (Ngwenya et al. 2020). Secondly, a challenge often faced within the informal sector concerns entrepreneurial activities and management practices. The extent of their influence on informal sector entrepreneurial performance becomes an avenue that also warrants further attention. Finally, economic growth interventions need to consider both formal and informal sector contributions (Burger \& Fourie 2019). In South Africa, much of the empirical effort is given towards the formal sector; calls exist, especially in the current economic climate, to pay attention to the informal sector (Ngwenya et al. 2020).

Given the above discussion, we argue that if entrepreneurship is to flourish in South Africa, entrepreneurial activities in the informal sector should not only be encouraged but equally researched. This provides a platform through which evidence-based practice can emerge that has ramifications for practice and also policy. All these efforts potentially have ramifications not only for informal sector development but also for local economic development. This study investigated factors that influence performance within the informal economy. The identified factors include (1) entrepreneurial culture, (2) entrepreneurial education and skills, (3) government and incubation support and finally, (4) access to finance.

\section{Context}

Like any other developing nation, South Africa is believed to have its share of socio-economic problems (Adeyemi et al. 2018). The South African economy has a high unemployment rate, high-income inequality, high crime rates, extreme poverty conditions and low living standards (Adeyemi et al. 2018). The unfavourable socio-economic conditions within South Africa have led many individuals to engage in informal sector activities (Bhatti et al. 2012). Alrawadieh and Alrawadieh (2018) highlighted that people in countries with an economically challenged and socially marginalised environment are forced to make venture creation decisions in their self-employment form. In South Africa, informal sector activities are deemed to be twice as large in number as activities in the formal economy (Herrington et al. 2010). Although in most developed countries, informal businesses are marginal in their contribution towards employment creation and a country's gross domestic product (Webb et al. 2013), in South African, they are critical to the livelihood and survival of millions of people (Herrington et al. 2010).

\section{The informal sector and entrepreneurship}

The informal sector represents a significant complement to the formal economy (Hartwell \& Malinowska 2019; Pankomera \& Greunen 2019). Fuentelsaz, González and Maicas (2019) and Pankomera and Greunen (2019) concurred with the previous observation and pointed out that the informal sector contributes more in some nations towards economic growth than the formal economy does. Thus, the informal sector can be thought of as a supporting element of the formal sector, especially in a period of difficulty (Ngwenya et al. 2020). Some even argue that formalised businesses could emerge from activities within the informal sector (Kedir, Williams \& Altinay 2018; Rankumise 2017). In support, Fuentelsaz et al. (2019) highlighted that the informal sector presents a set of motivating factors for economic agents in search of opportunities. These economic agents, as outlined by Serviere (2010), are forced to make venture creation decisions in their self-employment form. In other words, the informal sector provides an ideal platform for people to become entrepreneurs. Entrepreneurs are classified into the following three types: necessity, opportunity and serial entrepreneurs (Gibbs, Mahone \& Crump 2014; Pace 2015; Scarborough 2011).

In South Africa, the informal sector is an essential supporter of the formal sector, especially within the period of sustained economic challenge (Ngwenya et al. 2020). The informal sector's value is argued for as well because of the challenges imposed by the coronavirus disease 2019 (COVID-19) pandemic (Karrim 2020). There is an observation of more people entering the South African informal sector (Francis \& Valodia 2020). Furthermore, in South Africa, because of low start up costs, there is evidence showing the informal sector's popularity as a possible income generator for society (Cobbinah \& Chinyamurindi 2016). Some estimated figures predict about 2.5 million workers and business owners operating within the South African informal sector (Fourie 2018) and this number is believed to be growing (Burger \& Fourie 2019; Ngwenya et al. 2020). More recent statistics predict about $20 \%$ of South Africa's total employment within the informal sector (Statistics South Africa 2019).

\section{Firm performance}

Firm performance is the firm's operational ability to satisfy the desires of its owner(s) (Zulkiffli 2014). The term performance is often used interchangeably with the terms growth and success (Urban \& Kongo 2015). To establish whether the firm is succeeding or failing, its performance must be measured (Al-Matari, Al-Swidi \& Fadzil 2014; Velimirović, Velimirović \& Stanković 2011). Molefe (2010) highlighted that performance measurement monitors and reports how well a person or entity is doing. In concurrence, Velimirović et al. (2011) outlined that performance measurement enables firms to express their success and failure objectively and subjectively. In measuring firm's performance, managers compare (financial or nonfinancial) values with some planned value or benchmark (Shava \& Rungani 2016; Velimirović et al. 2011). In other words, previous research measures performance objectively and subjectively. The former places emphasis on quantifiable performance indicators (Shava \& Rungani 2016; Zehir, Can \& Karaboga 2015), whereas the latter places emphasis on non-financial measures (Vij \& Bedi 2016). 


\section{Factors influencing informal sector's entrepreneurial activity and their effect on firm's performance}

The study hinges on two main theories. Firstly, emphasising human and physical resources is the human capital theory (Becker 1964, 1993). The emphasis here is placed on those aspects that influence performance like natural resources, human resources and the presence of capital (Chinyamurindi 2017). Others (e.g. Bushe 2019) add aspects such as management, machines, materials and money. Concerning the people aspect and using the human capital theory, the informal entrepreneur (and other people working for them) has learning capacities that are of value in the performance of the venture, that is, the production of goods and services (Lucas 1990). Secondly, the resource-based view of the firm (Barney 1991) is also a theoretical consideration underpinning the study. The basic premise is that resources are a vital asset towards firm performance (Rothaermel 2012) by exploiting external opportunities and existing resources (Louw \& Venter 2013). Concerning the empirical literature, the focus is given to understanding how (1) entrepreneurial culture, (2) entrepreneurial education and skills, (3) government and incubation support and (4) access to finance as entrepreneurial activities influence firm performance. The empirical literature around this is discussed next.

\section{Entrepreneurship culture and firm performance}

Radipere (2014) outlined that a firm's culture determines a group's identity in the same way as personality determines the identity of an individual. Cornwall (2011) specified that a firm's culture reflects an entrepreneur's values that his employees bring to a firm. Culture helps people understand how one should treat customers and other employees, act on the job, fit in and succeed. If managed properly, a firm's culture improves its performance (Corritore, Goldberg \& Srivastava 2017). Considering that globally, the business environment is highly dynamic, unpredictable and competitive, businesses must possess entrepreneurial behaviours, develop supportive firm structures to survive, gain a competitive advantage and achieve superior performance (Otache \& Mahmood 2015).

According to Cornwall (2011), as an entrepreneurial culture is rooted in a firm's commitment to people and doing business, it helps the firm meet its customers' expectations, define the firm's authenticity and highlight the firm's effort towards attaining goals. However, a culture that discourages risk-taking and innovation can hinder strides essential for firm's efficiency and effectiveness. Previous studies (e.g. Alrawadieh \& Alrawadieh 2018; Heyman et al. 2019) found that entrepreneurial activities such as risk-taking and innovativeness, being proactive, autonomy and competitive aggressiveness have a positive relationship with profitability, market share, growth and overall business performance. Also, in a study conducted by Jiang et al. (2018), it was found that a firm's entrepreneurial culture/intrapreneurship is a valuable capability that leads to superior firm performance.
Furthermore, in the studies of Asieba and Nmadu (2018) and Palmer et al. (2019), entrepreneurship culture was found to lead to higher sales growth, market share growth and product and market development. Firms that can develop a working environment that supports innovation are most likely to achieve a higher number of product and process innovations, thereby increasing competitiveness. Thus, it can be concluded that there is a strong and positive relationship between entrepreneurial orientation and firm's performance (financial and non-financial performance) (Cowden, Tang \& Bendickson 2016).

\section{Entrepreneurial education and skills}

An analysis of the selected informal sector revealed that many informal sector traders have little entrepreneurial education or skills training (Hutchinson 2014; Lekhanya 2015; Mutanda, De Beer \& Myres 2015). Literature shows that two thirds of informal sector participants do not keep business records (Lekhanya 2015). This could be because of a lack of management and financial skills (Mutanda et al. 2015). Despite such skills deficiencies amongst informal sector entrepreneurs, Asieba and Nmadu (2018) observed that a significant number of those who lacked entrepreneurial and business skills/education were willing to undergo skills training.

According to Minai et al. (2018), entrepreneurial education is obtained through entrepreneurial learning - the process by which people acquire, assimilate and organise newly formed knowledge with pre-existing structures and how learning affects entrepreneurial action. Others (e.g. Leiva Alegre \& Monge 2014; Paltasing 2012) concurred that entrepreneurial education/learning is a lifelong learning process. All the accumulated knowledge that a person has gained throughout his or her life can contribute to setting up a new firm (Adjei et al. 2019). Efforts of entrepreneurial education can include learning from entrepreneurs' positive and negative experiences (Pagano, Petrucci \& Bocconcelli 2018). These experiences form a basis and platform for social learning into the world of entrepreneur careers (Adebayo, Awodun \& Ajonbadi 2016; Nkosi et al. 2015).

\section{Government and incubator support and firm performance}

The government creates a favourable climate for entrepreneurs by providing financial and non-financial support to potential, emerging and established entrepreneurs (Dvouletý et al. 2018). This support can determine the entrepreneurial ecosystem (Moro et al. 2020). The government can play an essential role in developing entrepreneurs and encouraging entrepreneurship education. These efforts include (1) creation of business incubators, (2) creation of platforms for networking, (3) offering mentoring and coaching to businesses and (4) financial and non-financial support (Lukeš, Longo \& Zouhar 2019; Mbatha 2015; Wei \& Lui 2015; Wu, Song \& Yang 2020). Previous studies institute that the government is biased towards supporting emerging micro-enterprises; hence, many informal traders fail (Hutchinson 2014; Webb et al. 2013). According to 
Dvouletý et al. (2018), to efficiently address, there is a need for government support in addressing challenges faced by small businesses and the informal sector. This becomes a functional feeder to an entire entrepreneurial ecosystem and a balance between those formally registered and those not registered.

\section{Access to finance and firm performance}

Several scholars concur that access to finance and firm performance are positively correlated (Fuentelsaz et al. 2019; Rogerson 2018; Sibanda, Hove-Sibanda \& Shava 2018). When firms have access to funding, it is presumed that the firms' value-added would increase (Fowowe 2017; Hartwell \& Malinowska 2019); the firms would have a competitive advantage and the capabilities to realise their objectives (Adomako \& Danso 2015; Esubalew \& Raghurama 2020). Rankumise (2017) posited that access to finance is critical for a firm to succeed in its business transactions. In a study conducted in Morocco by Fafchamps and Schndeln (2013), it was found that firms that secure funding from banks primarily invest in physical capital. This act of investing in physical capital, in turn, can lead a firm to increase employees' productivity, reduce labour costs and increase the firm's profitability (Allen, Qian \& Xie 2018; Heyman et al. 2019).

Given the preceding discussions, the study tests the following null and alternate hypotheses:

- Null hypothesis 1: A culture of entrepreneurship predicts subjective firm performance.

- Alternative hypothesis 1: A culture of entrepreneurship predicts objective firm performance.

- Null hypothesis 2: Entrepreneurial education and skills support for firms predict subjective firm performance.

- Alternative hypothesis 2: Entrepreneurial education and skills support for firms predict objective firm performance.

- Null hypothesis 3: Government and incubator support for firms predicts subjective firm performance.

- Alternative hypothesis 3: Government and incubator support for firms predicts objective firm performance.

- Null hypothesis 4: Access to finance for firms predicts subjective firm performance.

- Alternative hypothesis 4: Access to finance for firms predicts objective firm performance.

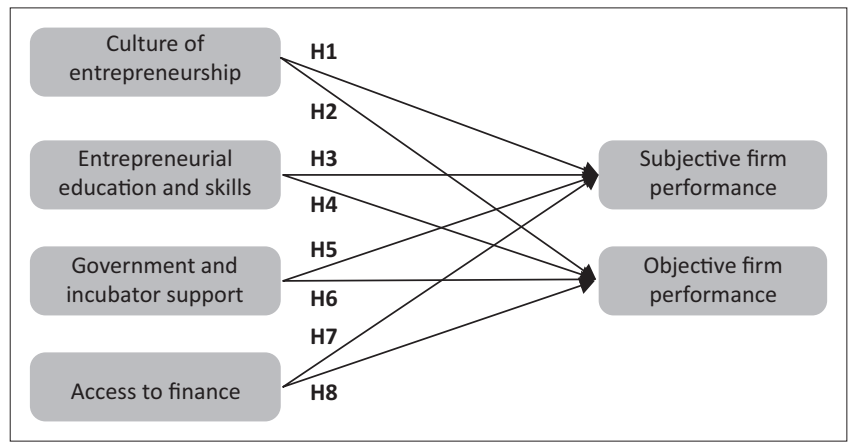

FIGURE 1: Conceptual model of informal sector entrepreneurial activity.
Figure 1 presents the research model for the study based on the research hypotheses presented.

\section{Method}

A quantitative approach hinging on a survey research technique was utilised (eds. Denzin \& Lincoln 2018; Du Plooy-Cilliers, Davis \& Bezuidenhout 2020). Through this approach and technique, the research team gathered collected data for statistical analysis purposes. A quantitative research method is a data-gathering technique that involves the collection and statistical analyses of numerical data to explain a concept. The study used a convenience sample consisting of 152 informal entrepreneurs who operated in Durban, South Africa. This sample usage allowed access to those respondents who were most available, given challenges in accessing a reliable sampling frame (Leedy \& Ormrod 2019). It should be mentioned, especially within the informal economy space in South Africa, that there is no reliable population tally of all informal businesses (Burger \& Fourie 2019; Mintah \& Darkwah 2018). This may be exacerbated by registration challenges, as most of these ventures are not registered (Ngwenya et al. 2020). The Durban central business district was used as a data collection point. Given the mentioned challenges of a reliable sampling frame, a total of 250 questionnaires were distributed randomly to informal trade businesses. From this number, a total of 152 were filled out correctly and deemed usable for this research. This yielded a response of $60 \%$ given the initial distribution of 250 questionnaires.

A self-administered questionnaire was used as a data collection tool. This allowed the researchers to potentially reach a large sample with a pre-determined set of questions (Saunders, Lewis \& Thornhill 2019). The scales utilised in the questionnaire were taken from previous studies, as shown in Table 1. All items were measured on a 5-point Likert scale.

The questionnaire gathered each participant's biographic data, opinions related to entrepreneurship and data measuring their firm's performance. Inferential statistics were used to make inferences from the chosen sample to a larger population (eds. Denzin \& Lincoln 2018). Pearson's correlation and simple linear regression (SLR) were used to test the study's hypotheses.

\section{Ethical considerations}

Ethical clearance was obtained from the University of Fort Hare Research Ethics Committee: CHI041TMKA01.

\section{Analysis and results Descriptive demographic data}

The study found the selected informal sector location to be dominated by male business owners. A total of 152 respondents participated in the study. By gender, $59.2 \%$ of the participants were male and $40.8 \%$ were female. 
TABLE 1: Scales used for the study.

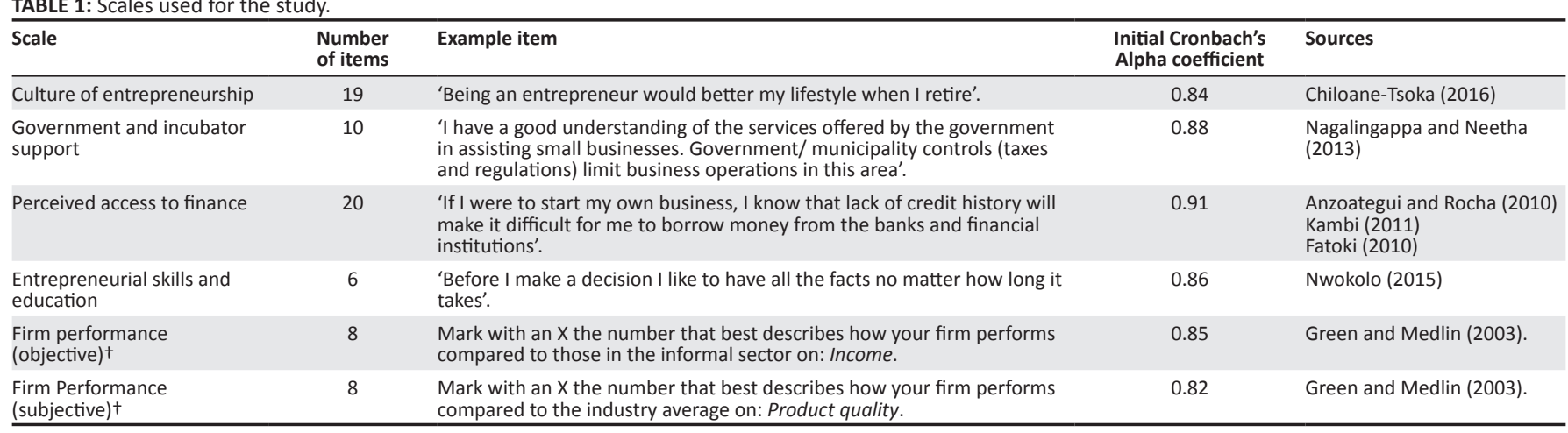

Note: Measured on a 5-point Likert scale from Weaker 12345 Stronger.

The majority of informal entrepreneurs $(92.76 \%)$ were aged between 20 and 50 years. Furthermore, the study established that informal entrepreneurship offers a decent revenue stream, enabling those involved to earn a decent lifestyle. The results established that around $53.29 \%$ of the total respondents earned a minimum of R1000 per week. Concerning the age of informal businesses, the study found that most informal firms (50.66\%) have been in operation for more than 2 years. Furthermore, the study established that most informal traders $(65.13 \%)$ had no employees and only $3.22 \%$ hired more than three employees. In terms of the informal businesses' description, the majority of businesses were in the service-commercial sector $(70 \%)$. This included traders and market vendors. A further $20 \%$ were operating in some form of artisan work - these included plumbers, mechanics and electricians. The majority of respondents cited being out of work or lack of employment opportunities as the reason to be working in the formal sector (95\%). Finally, $10 \%$ of the sample classified themselves as other outside these two identified categories. These informal businesses were operating mainly within the Durban central business district with no formal established place of operation (35\%) and utilising mostly municipality demarcated areas for trade $(65 \%)$. The informal sector's growth as a possible shock absorber to the formal sector's challenges (Ngwenya et al. 2020) ignited interest in this sample group and the context of the study.

\section{Pearson correlation and Cronbach's Alpha coefficients}

To investigate the relationship between the factors of entrepreneurship (culture of entrepreneurship, access to finance, government and incubator support and entrepreneurial education/skills) and firm's performance (objective and subjective), Pearson correlation and simple linear regression (SLR) analyses were undertaken. Pearson correlation results are displayed in Table 2.

The Pearson correlation test results in Table 2 reveal that adopting an entrepreneurship culture has a significantly weak to a moderately positive relationship with a firm's financial and non-financial performance, with $r=0.319$ and $r=0.309$, respectively. However, access to finance is negatively correlated with financial firm performance, $r=-0.012$, and non-financial performance, $r=-0.041$. Furthermore, all the scales appear to have sufficient ratings of reliability as recommended (Pallant 2011). Simple linear regression analysis was undertaken to test data on the hypotheses between the identified factors (entrepreneurial culture, access to finance, entrepreneurial education and government/ incubator support) and firm performance (subjective and objective). The results are shown in Table 3.

The results in Table 3 reveal that there is a positive relationship between the culture of entrepreneurship and the financial performance of the firm $(\beta=0.353 ; p=0.000)$. In other words, a unit increase in the culture of entrepreneurship leads to a corresponding increase in financial performance by 0.353 units. Given the indicated results, there is no sufficient evidence to reject the null hypothesis stating that entrepreneurial culture predicts financial performance at the 95\% confidence interval. The same applies to test data concerning Hypothesis 2, stating that a culture of entrepreneurship predicts objective firm performance. The results in Table 3 further indicate that there is a positive relationship between a culture of entrepreneurship and subjective performance of the firm $(\beta=0.256$ and a $p$-value of 0.000 ). The stated results indicate that a unit increase in entrepreneurial culture results in a corresponding 0.256 units increase in the subjective performance of the firm. From the stated results, there is no sufficient evidence to reject the null hypothesis stating that a culture of entrepreneurship predicts the non-financial performance of the firm at the $95 \%$ confidence interval. Thus, Hypotheses 1 and 2 of this study were supported.

Other tests conducted show that access to finance was found to have no unique contribution to both a firm's financial performance $(\beta=-0.020 ; p=0.879)$ and non-financial performance $(\beta=-0.049 ; p=0.617)$. The regression analysis output concerning access to finance and financial performance and non-financial performance is shown in Table 3. Based on the results, Hypothesis 3 stating that access to finance predicts financial performance is not supported at the $95 \%$ confidence interval. This conclusion also applies to Hypothesis 4 stating that access to finance predicts the nonfinancial performance of the firm. Thus, there is sufficient evidence to reject the null hypothesis stating that access to 
TABLE 2: Pearson correlation analysis results and Cronbach's Alpha coefficients.

\begin{tabular}{lccccc}
\hline $\begin{array}{l}\text { Scale and number of } \\
\text { items utilised }\end{array}$ & $\begin{array}{c}\text { Cronbach's Alpha } \\
\text { Coefficient }\end{array}$ & CE & AF & GIS & EES \\
\hline CE [16 items] & 0.73 & - & - & - & OF \\
AF [15 items] & 0.71 & 0.163 & - & - & - \\
GIS [10 items] & 0.75 & $-0.161^{*}$ & 0.093 & - & - \\
EES [6 items] & 0.83 & $0.405^{* *}$ & -0.119 & -0.144 & - \\
OF [8 items] & 0.87 & $0.319 * *$ & -0.012 & $0.169 *$ & - \\
SNF [8 items] & 0.78 & $0.309^{* *}$ & -0.041 & -0.010 & - \\
\hline
\end{tabular}

$\mathrm{AF}$, Access to finance; $\mathrm{CE}$, culture of entrepreneurship; $\mathrm{EES}$, entrepreneurial education/skills; GIS, government and incubator support; OF, Objective, financial measures; SNF, subjective, non-financial measures.

*Correlation significant at the 0.05 level (2-tailed).

**Correlation significant at the 0.01 level (2-tailed).

TABLE 3: SLR analysis outcome.

\begin{tabular}{|c|c|c|c|c|c|c|c|}
\hline \multirow[t]{2}{*}{ Tested relationship } & \multicolumn{2}{|c|}{$\begin{array}{l}\text { Unstandardised } \\
\text { Coefficients }\end{array}$} & \multicolumn{2}{|c|}{ Std error } & \multicolumn{2}{|c|}{$t$} & \multirow[t]{2}{*}{ Sig. } \\
\hline & B & Std error & Constant & $\begin{array}{l}\text { Dependent } \\
\text { variable }\end{array}$ & Constant & $\begin{array}{l}\text { Independent } \\
\text { variable }\end{array}$ & \\
\hline H1: Entrepreneurial culture with financial performance & 2.442 & 0.353 & 0.326 & 0.086 & 7.483 & 4.121 & 0.000 \\
\hline H2: Entrepreneurial culture with non-financial performance & 2.869 & 0.256 & 0.245 & 0.064 & 11.716 & 3.984 & 0.000 \\
\hline H3: Access to finance with financial performance & 3.842 & -0.020 & 0.450 & 0.132 & 8.529 & -0.152 & 0.879 \\
\hline H4: Access to finance with non-financial performance & 4.003 & -0.049 & 0.337 & 0.099 & 11.891 & -0.501 & 0.617 \\
\hline H6: Entrepreneurial education with non-financial performance & 2.170 & 0.420 & 0.288 & 0.072 & 7.527 & 5.814 & 0.000 \\
\hline H7: Government/incubator support with financial performance & 3.377 & 0.156 & 0.196 & 0.074 & 17.345 & 2.100 & 0.037 \\
\hline H8: Government/incubator support with non-financial performance & 3.854 & -0.007 & 0.148 & 0.056 & 26.084 & -0.127 & 0.899 \\
\hline
\end{tabular}

SLR, Simple linear regression.

finance predicts the non-financial performance of the firm at the $95 \%$ confidence interval.

This study also reveals that as firm owners' entrepreneurial education/skills increase, so does the financial and nonfinancial performance of their business. In the presentation of results, entrepreneurial education is significantly and positively related to financial performance of the firm $(\beta=0.452 ; p=0.000)$ (see Table 3$)$. The results also indicate that there is a significant positive relationship between entrepreneurial education and non-financial performance $(\beta=0.420 ; p=0.000)$. Therefore, the hypothesis stating that entrepreneurial education and skills predict financial performance and non-financial performance was supported at a 95\% confidence interval. Concerning government support and incubation activities, the results in Table 3 show that an increase in a firm's financial performance $(\beta=0.156$; $p=0.037)$ has a significant effect on a firm's non-financial performance $(\beta=-0.007 ; p=0.899)$. The results in Table 3 also show that government and incubation support predicted financial performance and this is supported at a $95 \%$ confidence level.

\section{Discussion of findings}

This study sought to understand the link between informal sector entrepreneurial activities and firm performance using a sample of firms operating in Durban, South Africa. These findings especially focused on the informal sector as an important aspect of a country's economy (Fu et al. 2018). Uniquely, the findings focused on factors that are deemed important in assisting how businesses in the informal economy perform (Mintah \& Darkwah 2018). By observation from the respondents, it emerges that largest proportion responded their entry and operation within the informal economy to be influenced by challenges of unemployment. This supports previous research showing the role of unemployment as facilitating entrance and operation within the informal sector (Alrawadieh \& Alrawadieh 2018; Başbay et al. 2018).

The research and its findings contribute further to previous South African research related to the informal sector (Ngwenya et al. 2020). This study highlights factors that can be deemed important towards informal sector entrepreneurial performance. A group of related factors concern not only the necessity of the creation of an entrepreneurial culture but also the importance of entrepreneurial education and skills. These become important pre-conditions for success. This shift towards the informal sector (as proposed by this research) becomes important especially within a South African context facing a number of economic challenges (Burger \& Fourie 2019). The argument here can be that despite informal traders not being registered (Pankomera \& Greunen 2019), nothing stops them from exercising some form of structure to the way they are run. As found in this study, it can be made sure that some form of structure and organisation in the form of an entrepreneurial culture is in place. This can be an important endeavour that the individual entrepreneur not only prioritises but also makes sure that it is continual. Linked to this can be the effort to attain education, training and skills that assist informal traders in the work they do. Ultimately, based on these identified factors, those operating within the informal entrepreneurial space have an opportunity to improve not only how they operate but also the performance of their entities. This could support the view arguing that from businesses in the informal 
sector as expressed by their activities, formalised business entities can exist (Kedir et al. 2018; Rankumise 2017). The informal sector context becomes an important learning ground to all this.

\section{Implications and recommendations}

This study has provided evidence that the informal sector contributes to the economy of a nation, particularly in providing employment. This investigation, besides revealing that the majority of participants are within the working age (20-50 years), has also revealed that one can earn a decent income from the informal sector. With these findings, this study argues that the informal sector can be used as a starting place for prospective entrepreneurs. Furthermore, although literature characterises informal sector firms as stagnant, poor performing and prone to failure (Hutchinson 2014, Lekhanya 2015), the fact that this study has found the average age of firms operating in the informal sector to be above 2 years gives hope and time for intervention measures that could enhance firm performance.

Some research implications can be drawn from this study. The study despite answering calls for more research studies into the South African informal sector (Ngwenya et al. 2020) also continues for such calls. Future research could consider qualitative research methods to understand ensuing complexity that accompanies informal sector's entrepreneurial development. An agenda for informal sector research can also be proposed that can be understood by comparison of experiences of entrepreneurs in such a sector. This could take the form of accounting for geographical and gender variation. Given the current economic climate and the notable move by many from the formal to the informal sector (Ngwenya et al. 2020), such research should be prioritised.

The study's results further indicate that firm's owners increasingly adopt an entrepreneurial culture and this act correspondingly results in increased performance. This entails that all societal facets have huge roles to play in improving the entrepreneurial environment if entrepreneurial firms are to flourish. Furthermore, the results of this study have outlined that for entrepreneurial activities to flourish, firm's managers and owners should possess business education/entrepreneurial skills. Firm owners/managers are advised to pursue entrepreneurial/business education for them to effectively manage their firms.

\section{Limitations of this study and areas for future research}

The research sample of this study was limited to informal sector entrepreneurs operating in Durban. The data collected in the study were from a single location in the city, thereby limiting the generalisation of this study's findings. Collecting data from multiple locations would improve the generalisation reliability of the study. Instead of focusing on a broad topic like entrepreneurial activity or firm's performance and analysing multiple variables (an entrepreneurial culture, government support, entrepreneurial education and access to finance), future research could analyse one or two variables. This would produce in-depth information on the variable/variables under analysis.

\section{Conclusion}

The goal of this study was to investigate the relationship between informal sector entrepreneurial activity and firm performance in the Durban Metropolitan area. An analysis was conducted and the findings from the analysis highlighted who in the informal sector are entrepreneurs, how they operate in the informal sector and the problems they face in operating their firms. Furthermore, how major entrepreneurial factors like an entrepreneurial culture, access to finance, entrepreneurial education/skills and government and incubator support impact firm performance was discussed in light of the findings. From the study's findings, conclusions and recommendations were drawn.

\section{Acknowledgements}

The authors would like to acknowledge the financial support for the entire project from the South African National Research Foundation and the Durban University of Technology.

\section{Competing interests}

The authors declare that no competing interests exist.

\section{Authors' contributions}

T.N. wrote this article under the supervision of W.T.C.

\section{Funding information}

This work was supported by the National Research Foundation.

\section{Data availability}

Data sharing is not applicable to this article as now new data were created or analysed in this study.

\section{Disclaimer}

The views and opinions expressed in this article are those of the authors and do not necessarily reflect the official policy or position of any affiliated agency of the authors.

\section{References}

Adebayo, P.O., Awodun, M. \& Ajonbadi, H.A., 2016, 'Capacity building and supportive infrastructural network for rural entrepreneurial development in Kwara State', International Journal of Information Research and Review 3(2), 1816-1824.

Adeyemi, R.A., Joel, A., Ebenezer, JT. \& Attah, EY, 2018, 'The effect of brain drain on the economic development of developing countries: Evidence from selected African countries', Journal of Health and Social Issues 7(2), 66-76. 
Adjei, E.K., Eriksson, R.H., Lindgren, U. \& Holm, E., 2019, 'Familial relationships and firm performance: The impact of entrepreneurial family relationships' Entrepreneurship and Regional Development 31(5-6), 357-377. https://doi.org/ Entrepreneurship and Regional Devel
$10.1080 / 08985626.2018 .1514074$

Adomako, S. \& Danso, A., 2014, 'Financial literacy and firm performance: The moderating role of financial capital availability and resource flexibility', International Journal of Management \& Organisational Studies 3(4), 1-15.

Allen, F., Qian, M. \& Xie, J., 2018, 'Understanding informal financing', Journal of Financial Intermediation 39(1), 19-33. https://doi.org/10.1016/j.jfi.2018.06.004

Al-Matari, E.A., Al-Swidi, K.A. \& Fadzil, F.A., 2014, 'The measurements of firm performance's dimensions', Asian Journal of Finance \& Accounting 6(1), 24-41. https://doi.org/10.5296/ajfa.v6i1.4761

Alrawadieh, Z. \& Alrawadieh, Z., 2018, 'Exploring entrepreneurship in the sharing accommodation sector: Empirical evidence from a developing country', Tourism Management Perspectives 28(1), 179-188. https://doi.org/10.1016/j. tmp.2018.09.001

Anzoategui, D. \& Rocha, R., 2010, The competition of banks in the Middle East and Northern Africa region, Policy Research Working Paper 5363, World Bank, Washington, DC

Asieba, I.O. \& Nmadu, T.M., 2018, 'An assessment of the impact of entrepreneurial skills of community pharmacists on pharmaceutical business performance in Jos metropolis, Nigeria', Pharmacy Practice 16(1), 1-7. https://doi.org/10.18549/ PharmPract.2018.01.1110

Barney, J., 1991, 'Firm resources and sustained competitive advantage', Journal of Management 17(1), 99-120. https://doi.org/10.1177/014920639101700108

Başbay, M.M., Elgin, C. \& Torul, O., 2018, Socio-demographics, political attitudes, and informal sector employment: A cross-country analysis, Economic Systems 42(4), 556-568. https://doi.org/10.1016/j.ecosys.2018.03.003

Becker, G.S., 1964, Human capital: A theoretical and empirical analysis, with special reference to education, Colombia University Press, New York, NY.

Becker, G.S., 1993, Human capital: A theoretical and empirical analysis with special reference to education, University of Chicago Press, Chicago, IL.

Bhatti, N., Memon, M.A., Shah, A.B. \& Shaikk, F.M., 2012, 'Women entrepreneur challenge in business development and employment in Khairphu Mors- SindhPakistan', Australian Journal of Business and Management Research 2(1), 58-63.

Bozhikin, I., Macke, J. \& Da Costa, L.F., 2019, 'The role of government and key non-state actors in social entrepreneurship: A systematic literature review', Journal of Cleane Production 226(1), 730-747. https://doi.org/10.1016/j.jclepro.2019.04.076

Burger, P. \& Fourie, F., 2019, 'A high unemployment and labour market segmentation A three-segment macroeconomic model', South African Journal of Economic and Management Sciences 22(1), 1-12. http://doi.org/10.4102/sajems.v22i1.2103

Bushe, B., 2019, 'The causes and impact of business failure among small to micro and medium enterprises in South Africa', Africa's Public Service Delivery and Performance Review 7(1), 210-215. https://doi.org/10.4102/apsdpr.v7i1.210

Chiloane-Tsoka, G.E., 2016, 'Factors influencing the perceptions of youth entrepreneurship development in South Africa', Problems and Perspectives in Management 14(3-2), 556-563. https://doi.org/10.21511/ppm.14(32).2016.12

Chinyamurindi, W.T., 2017, 'The role of information management in project management success: Narratives from entrepreneurs operating within the South management success: Narratives from entrepreneurs operating within the South 19(1), 1-9. https://doi.org/10.4102/sajim.v19i1.811

Cobbinah, C. \& Chinyamurindi, W.T., 2016, 'Motivational factors for engaging in dirty work entrepreneurship among a sample of African immigrant entrepreneurs in Work entrepreneurship among a sample of African immigrant entrepreneurs in a1025. https://doi.org/10.4102/sajhrm.v16i0.1025

Cornwall, J., 2011, Building an entrepreneurial culture: The entrepreneurial mind viewed 06 June 2016, from http://www.businessinsider.com.building-anentrepreneurial-culture-2011-8.

Corritore, M., Goldberg, A. \& Srivastava, S.B., 2020, 'Duality in Diversity: How Intrapersonal and Interpersonal Cultural Heterogeneity Relate to Firm Performance', Administrative Science Quarterly, 65(2), 359-394.

Cowden, B., Tang, J. \& Bendickson, J., 2016, 'The maturing of entrepreneurial firms: Entrepreneurial orientation, firm performance, and administrative heritage', New England Journal of Entrepreneurship 19(2), 41-53. https://doi.org/10.1108/NEJE19-02-2016-B004

Denzin, N.K. \& Lincoln, Y.S. (eds.)., 2018, The SAGE handbook of qualitative research, Sage, Los Angeles, CA.

Du Plooy-Cilliers, F., Davis, C. \& Bezuidenhout, R.M., 2020, Research matters, Juta, Claremont.

Dvouletý, O., Longo, M.C., Blažková, I., Lukeš, M. \& Andera, M., 2018, 'Are publicly funded Czech incubators effective? The comparison of performance of supported and non-supported firms', European Journal of Innovation Management 21(4), 543-563. https://doi.org/10.1108/EJIM-02-2018-0043

Esubalew, A.A. \& Raghurama, A., 2020, 'The mediating effect of entrepreneur's competency on the relationship between Bank finance and performance of micro small, and medium enterprises', European Research on Management and Business Economics 26(2), 87-95. https://doi.org/10.1016/j.iedeen.2020.03.001

Fafchamps, M. \& Schundeln, M., 2013, 'Local financial development and firm performance: Evidence from Morocco', Journal of Development Economics 103(1) 15-28. https://doi.org/10.1016/j.jdeveco.2013.01.010

Fatoki, O.O., 2010, 'Graduate entrepreneurial intention in South Africa: Motivations and obstacles', International Journal of Business and Management 5(9), 87-98. https://doi.org/10.5539/ijbm.v5n9p87
Fourie, F., 2018, The South African informal sector: Creating jobs, reducing poverty, Cape Town, HSRC Press.

Fowowe, B., 2017, 'Access to finance and firm performance: Evidence from African countries', Review of Development Finance 7(1), 6-17. https://doi.org/10.1016/j. rdf.2017.01.006

Francis, D. \& Valodia, I., 2020, South Africa needs to focus urgently on how COVID-19 will reshape its labour market, viewed 23 January 2021, from https://www.wits. ac.za/scis/publications/opinion/sa-needs-to-focus-on-how-covid-19-willreshape-labourmarket/.

Fu, X., Mohnen, P. \& Zanello, G., 2018, 'Innovation and productivity in formal and informal firms in Ghana', Technological Forecasting and Social Change 131(C), 315-325. https://doi.org/10.1016/j.techfore.2017.08.009

Fuentelsaz, L., González, C. \& Maicas, J.P., 2019. 'Formal institutions and opportunity entrepreneurship. The contingent role of informal institutions', Business Research Quarterly 22(1), 5-24. https://doi.org/10.1016/j.brq.2018.06.002

Gibbs, S.R., Mahone, J.R. \& Crump, M.E.S., 2014. 'A framework for informal economy entry: Socio-spatial, necessity-opportunity, and structural-based factors', Academy of Entrepreneurship Journal 20(2), 33-58.

Global Entrepreneurship Monitor, 2019, An alarmingly low level of entrepreneuria activity in spite of high unemployment, viewed 20 June 2018, from https://www. gemconsortium.org/report/gem-2018-2019-global-report.

Green, K.W. \& Medlin, B., 2003, 'The strategic planning process: The link between mission statement and performance', Academy of Strategic Management Journa 2(1), 23-32.

Hartwell, C.A. \& Malinowska, A.P., 2019, Informal institutions and firm valuation, viewed 20 June 2018, from https://doi.org/10.1016/j.ememar.2019.03.001

Herrington, M., Kew, J. \& Kew, P., 2010, Global Entrepreneurship Monitor, University of Cape Town, Cape Town.

Heyman, F., Norbäck, P.J., Persson, L. \& Andersson, F., 2019, 'Has the Swedish business sector become more entrepreneurial than the US business sector?', Research Policy 48(7), 1809-1822. https://doi.org/10.1016/j.respol.2019.04.007

Hutchinson, M.V., 2014, 'Factors that limit the long-term survival and development of micro and survivalist enterprises of a selected informal sector in Durban, KwaZuluNatal (KZN)', M-Tech dissertation, Durban University of Technology, Durban.

Jiang, X., Liu, H., Fey, C. \& Jiang, F., 2018, 'Entrepreneurial orientation, network resource acquisition, and firm performance: A network approach', Journal of Business Research 87(1), 46-57. https://doi.org/10.1016/j.jbusres.2018.02.021

Kambi, B., 2011, 'University students' entrepreneurial intentions in Tanzania: Case study: Mzumbe University', Master's thesis, Mzumbe University.

Karrim, A., 2020, Millions have lost their jobs during the lockdown, impacting socia welfare and food poverty, viewed 23 January 2021 from https://www.news 24 welfare and food poverty, viewed 23 January 2021, from https://www.news24.
com/news24/southafrica/news/millions-have-lost-their-jobs-during-the$\mathrm{com} / \mathrm{news} 24 / \mathrm{south}$ africa/news/millions-have-lost-their-jo
lockdown-impactingsocial-welfare-and-food-poverty-20200716.

Kedir, A.M., Williams, C. \& Altinay, L., 2018, 'Services industries and the informa economy: An introduction', The Service Industries Journal 38(11-12), 645-649. https://doi.org/10.1080/02642069.2018.1486959

Leedy, P.D. \& Ormrod, J.E., 2019, Practical research: Planning and design, 12th edn. Pearson, Upper Saddle River, NJ.

Leiva, J.C., Alegre, J. \& Monge, R., 2014, 'The influence of entrepreneurial learning in new firms' performance: A study in Costa Rica', Revista Innova Journal 24(1) 130-140. https://doi.org/10.15446/innovar.v24n1spe.47563

Lekhanya, L.M., 2015, 'Public outlook on small and medium enterprises as a strategic tool for economic growth and job creation in South Africa', Journal of Governance and Regulation 4(4), 412-418. https://doi.org/10.22495/jgr_v4_i4_c3_p7

Louw, L. \& Venter, P., 2013, Strategic management: Developing sustainability in Southern Africa, 3rd edn., Oxford University Press, Cape Town.

Lucas, R., 1990, 'Why doesn't capital flow from rich to poor countries?', American Economic Review 80(1), 6-92.

Lukeš, M., Longo, M.C. \& Zouhar, J., 2019, 'Do business incubators really enhance entrepreneurial growth? Evidence from a large sample of innovative Italian startups', Technovation 82-83(1), 25-34. https://doi.org/10.1016/j.technovation. 2018.07.008

Mbatha, N.P., 2015, 'An investigation of selected financial management fundamentals influencing financial stability of small and medium enterprises in Durban', Masters dissertation, Durban University of Technology, Durban.

Meyer, N., Molefe, K. \& De Jongh, J.J., 2018, 'Managerial challenges within SMEs: The case of a developing region', Polish Journal of Management Studies 18(2), 185-196.

Minai, M.S., Raza, S., Hashim, N.A., Zain, A.Y. \& Tariq, T.A. 2018, 'Linking entrepreneuria education with firm performance through entrepreneurial comptencies: A proposed conceptual framework', Journal of Entrepreneurship Education 21(4) $1-9$.

Mintah, S. \& Darkwah, S., 2018, 'Drivers of informal sector participation of small and medium enterprises in Ghana', Scientia Agriculturae Bohemica 49(1), 60-67. https://doi.org/10.2478/sab-2018-0010

Moro, A., Maresch, D., Fink, M., Ferrando, A \& Piga, C, 2020, 'Spillover effects of government initiatives fostering entrepreneurship on the access to bank credit for entrepreneurial firms in Europe', Journal of Corporate Finance 62(1). Article ID 101603, https://doi.org/10.1016/j.jcorpfin.2020.101603

Mutanda, M., De Beer, M. \& Myres, G.T., 2015, 'The perception of small and micro enterprises in the city of Durban Central Business District (CBD) (Kwazulu-Natal) (KZN) towards financial planning', Mediterranean Journal of Social Sciences 5(6) 153-163. https://doi.org/10.5901/mjss.2014.v5n6p153 
Nagalingappa, G. \& Neetha, K.V., 2013, 'Multiplying entrepreneur: Upholding entrepreneurship: A case study of a unique model and an initiative to encourage entrepreneurship in a small but strong way', Asian Pacific Journal of Management entrepreneurship in a small but strong way',
and Entrepreneurship Research 2(2), 60-70.

Ngwenya, M., Blauw, P.F., Pretorius, A., Claassen, C. \& Schenck, R., 2020, 'Skills-related underemployment amongst South Africa's informall employed and self-employed A case study of Potchefstroom', South African Journal of Human Resources Management 18(1), 1-12. https://doi.org/10.4102/sajhrm.v18i0.1308

Nkosi, E., Bounds, M, Thomas, A. \& Goldman, G., 2015, 'Skills required for the management of black owned small enterprises in Soweto', Acta Commercii 13(1), 1-10. https://doi.org/10.4102/ac.v13i1.186

Nwokolo, E., 2015, 'Entrepreneurship education as a strategy for the promotion of entrepreneurship culture and poverty reduction among university students', Master's Degree in the Faculty of Management and Commerce dissertation, University of Fort Hare.

Otache, I. \& Mahmood, R., 2015, 'Corporate entrepreneurship and business performance: The role of external environment and organisational culture: $A$ proposed framework', Mediterranean Journal of Social Sciences 6(4), 524-531. https://doi.org/10.5901/mjss.2015.v6n4s3p524

Pace, B., 2015, 4 Types of entrepreneurs: What type are you? viewed 20 June 2018 from http://www.omnithrive.com/4-type-of-entrepreneurs-what-type-are-you.

Pagano, A., Petrucci, F. \& Bocconcelli, R., 2018, 'A business network perspective on unconventional entrepreneurship: A case from the cultural sector', Journal of Business Research 92(1), 455-464. https://doi.org/10.1016/j.jbusres.2018.07.012

Pallant, J., 2011, SPSS survival manual: A step by step guide to data analysis using the SPSS program, 4th edn., Allen \& Unwin, Berkshire.

Palmer, C., Niemand, T., Stöckmann, C., Kraus, S. \& Kailer, N., 2019, 'The interplay of entrepreneurial orientation and psychological traits in explaining firm performance', Journal of Business Research 94(1), 183-194. https://doi. org/10.1016/j.jbusres.2017.10.005

Paltasing, T., 2012, 'Entrepreneurship education \& culture of enterprise: Relevance \& policy issues', Indian Journal of Industrial Relations 48(2), 233-246.

Pankomera, R. \& Greunen, D., 2019, 'Opportunities, barriers, and adoption factors of mobile commerce for the informal sector in developing countries in Africa: A systematic review', The Electronic Journal of Information Systems in Developing Countries 85(1), 1-18. https://doi.org/10.1002/isd2.12096

Radipere, S., 2014, 'The effects of culture as a startup factor on business performance', Problems and Perspectives in Management 12(4), 141-154.

Rankumise, E.M., 2017, 'Realities and challenges of running SMME's in Mpumalanga, South Africa and Chuzhou, China', in The 1st International Conference on Entrepreneurship Development (ICED), Bloemfontein, South Africa, April 03 to 05, 2019, pp. 56-64.

Rogerson, C.M., 2018, 'Informal sector city tourism: Cross-border shoppers in Johannesburg', Journal of Tourism and Geosites 22(2), 381-392. https://doi. org/10.30892/gtg.22209-296
Rothaermel, F.T., 2012, Strategic management: Concepts and cases, McGraw-Hill, London.

Saunders, M., Lewis, P. \& Thornhill, A., 2019, 'Collecting primary data using questionnaires', in M. Saunders, P. Lewis \& A, Thornhill (eds.), Research methods for business students, pp. 360-413, Pitman Publishing, London.

Scarborough, N.M., 2011, Essentials of entrepreneurship and small business management, Pearson Education, Upper Saddle River, NJ.

Serviere, L., 2010, 'Forced into entrepreneurship: Modeling the factors behind necessity entrepreneurship', Journal for Business and Entrepreneurship 22(1), 37-53.

Shava, H. \& Rungani, E.C., 2016, 'Influence of gender on SME performance in emerging economies', Acta Commercii 16(1), 1-9. https://doi.org/10.4102/ac.v16i1.408

Sibanda, K., Hove-Sibanda, P. \& Shava, H., 2018, 'The impact of SME access to finance and performance on exporting behavior at the firm level: A case of furniture manufacturing SMEs in Zimbabwe', Acta Commercii 18(1), 1-13. https://doi. org/10.4102/ac.v18i1.554

Statistics South Africa, 2019, Quarterly Labour Force Survey: Quarter 2: 2019, viewed 23 January 2021, from http://www.statssa.gov.za/publications/P0211/ P02112ndQuarter2019.pdf.

Urban, U. \& Kongo, M., 2015, 'The relevance of human capital to firm performance: A focus on the retail industry in Kinshasa, Democratic Republic of Congo', Acto Commercii 15(1), 1-9. https://doi.org/10.4102/ac.v15i1.261

Velimirović, D., Velimirović, M. \& Stanković, R., 2011, 'Role and importance of key performance indicators measurement', Serbian Journal of Management 6(1), 63-72. https://doi.org/10.5937/sjm1101063V

Vij, S. \& Bedi, H.S., 2016, 'Are subjective business performance measures justified?', International Journal of Productivity and Performance Management 65(5), 603-621. https://doi.org/10.1108/JJPPM-12-2014-0196

Webb, J.W., Bruton, G.D., Tihanyi, L. \& Ireland, R.D., 2013, 'Research on entrepreneurship in the informal economy: Framing a research agenda', Journal of Business Venturing, 28(5), 598-614. https://doi.org/10.1016/j.jbusvent.2012.05.003

Wei, J. \& Liu, Y., 2015, 'Government support and firm innovation performance: Empirical analysis of 343 innovative enterprises in China', Chinese Management Studies 9(1), 38-55. https://doi.org/10.1108/CMS-01-2015-0018

Wu, A., Song, D. \& Yang, Y., 2020, 'Untangling the effects of entrepreneurial opportunity on the performance of peasant entrepreneurship: The moderating roles of entrepreneurial effort and regional poverty level', Entrepreneurship \& RegionalDevelopment32(1-2),112-133.https://doi.org/10.1080/08985626.2019. Regional
1640479

Zehir, C., Can, E. \& Karaboga, T., 2015, 'Linking entrepreneurial orientation to firm performance: The role of differentiation strategy and innovation performance', Procedia - Social and Behavioral Sciences 210(1), 358-367. https://doi. org/10.1016/j.sbspro.2015.11.381

Zulkiffli, S.N., 2014, 'Business performance for SMEs: Subjective or objective measures', Review of Integrative Business and Economics Research 3(1), 371-381. 